\section{OCTOBER MEzTHES}

Oct. 2-4. Monoclonal Antibodies: Basic Principles, Experimental and Clinical Applications in Endocrinology. Florence, Italy. Info: Ares-Serono Symposia, Via Ravenna 8,00161 Rome, Italy

Oct. 3-5. DECHEMA Annual Meeting of Biotechnologists. Frankfurt, F.R.G. Info: DECHEMA, Postfach 9701 46, D-6000 Frankfurt am Main 97, F.R.G

Oct. 7-9. Update in Molecular Biology 1985: Genes and Systems in Development. San Francisco, CA. Info: Nature Update in Molecular Biology, Nature Publishing Co., 65 Bleecker St., New York, NY 10012

Oct. 7-9. Biotechnology in the Food Processing Industry. Minneapolis, MN. Info: Lynette Marten, University of Minnesota, Office of Special Programs, 405 Coffey Hall, 1420 Eckles Ave., St. Paul, MN 55108

Oct. 8. Lymphokines-The New Super Drugs? Info: Helen Raquet, Oyez Scientific \& Technical Services, Bath House, 3rd Floor, 56 Holbrook Viaduct, London ECI, U.K.

Oct. 8-10. Biotechnica '85. Hannover, F.R.G. Info: Deutsche Messeund Ausstellungs-AG, Messegelände, D-3000 Hannover 82, F.R.G.

Oct. 15-17. Biotec 85. Dusseldorf, F.R.G, Info: Dusseldorf Trade Shows, 500 Fifth Ave., New York, NY 10110

Oct. 17-18. The Eukaryotic Gene: Structure, Expression and Regulation. Chicago, IL. Info: Office of Continuing Medical Education, The University of Chicago, 5841 Maryland, Box 139, Chicago, IL 60637

Oct. 17-18. 2nd European Seminar and Exhibition on Computer-Aided Molecular Design. Basel, Switzerland. Info: See for Oct. 8.

Oct. 20-23. Fourth Carolina Conference on Gene Transfer and Expression. Rougemont, NC. Info: Diane G. Lawton, University of North Carolina, Program in Molecular Biology \& Biotechnology, 402 Swing Building $217 \mathrm{H}$, Chapel Hill, NC 27514

Oct. 20-23. International Symposium on Laboratory Robotics ' 85. Boston, MA. Info: International Symposium on Laboratory Robotics,
Zymark Corp., Zymark Center, Hopkinton, MA ()1748

Oct. 21-23. Biotech 85 USA. Washington, D.C. Info: Online Conferences, Pinner Green House, Ash Hill Drive, Pinner, Middlesex HA5 2AE, U.K.

Oct. 24-25. Engineering Profits in Biotechnology. Washington, D.C. Info: Ray Goodwin, CONRESCO, 6 Northbrook Park, Lexington, MA 02173 (also November 21-22 in Los Angeles, CA)

\section{movanas meatues}

Nov. 5-8. Bio 85 Japan. Osaka, Japan. Info: Osaka Conference Bureau, c/o Osako Chamber of Commerce and Industry, 58-7 Hashizume-cho, Uchihonmachi, Higashiku, Osaka 540, Japan

Nov. 11-15. 4th International Symposium on Anaerobic Digestion. Guangzhou, China. Info: General Secretariat, 4th International Symposium on Anaerobic Digestion, Ministry of Agriculture, Animal Husbandry and Fishery, Beijing, People's Republic of China

Nov. 18-19. Biological Pharmaceuticals... The Real World. Parsippany, NJ. Info: Sharon Barret Curry, President, Communitech Market Intelligence, P.O. Box 67, Yorktown Heights, NY 10598

Nov. 20. Seminar on Biotechnology Information. London, U.K. Info: EBIP, 9 Kean St., London WC2B 4AT, U.K.

Nov. 21-22. 1st International Conference on Protein Engineering. London. Info: See for Oct. 8

Nov. 27-29. Biotech 85 Asia. Singapore. Info: See for Oct. 21-23

\section{DECAMBR METTLES}

Dec. 9-11. 7th Miami International Conference on Alternative Energy Sources. Miami Beach, FL. Info: Clean Energy Research Institute, University of Miami, P.O. Box 248294, Coral Gables, FL 33124

Dec. 11-13. 1st IFAC Symposium on Modelling and Control of Biotechnological Processes. Noordwijkerhout, The Netherlands. Info: IFAC/Bio ' 85 c/o KIvI, P.O. Box 30424, 2500 GK The Hague, The Netherlands

\section{CONings}

Nov. 8-10. Introduction to Biotechnology and Bioprocesses. Chicago, IL. Info: American Institute of Chemical Engineers, 345 East 47th St., New York, NY 10017

Nov. 12-15. Fermentation Biotechnology. East Brunswick, NJ. Info: The Center for Professional Advancement, P.O. Box 964, East Brunswick, NJ 08816-0964

Nov. 14-15. After the Cloning Is Over: Process Development in Biotechnology. Chicago, IL. Info: See course for Nov. 8-10

Nov. 15-17. Genetic Engineering: A Short Course. Chicago, IL. Info: James Bailey, BRE Systems, 1665 East Mountain Street, Pasadena, CA 91104

\section{EXECUINE CHANCES}

Nova Pharmaceutical Corp. (Baltimore, MD) named Hans Mueller executive vice president, and elected Alfred Gilman and Michael Brown to its scientific advisory board.

Advanced Genetic Sciences (Greenwich, (T) named Joseph Bouckaert chief executive officer. He succeeds founder Daniel D. Adams, who remains chairman.

Biogen (Cambridge, MA) appointed Charles J. Cassamento vice president for marketing and licensing.

Synbiotics (Rancho Bernardo, CA) named Morton A. Vodian director of $\mathrm{R} \& \mathrm{D}$.

Monoclonal Antibodies (Mountain View, CA) elected J. George Harris, president of Health Group, Inc., to its board of directors.

Cetus Corp. (Emeryville, CA) promoted Hollings Renton to executive vice president and Behzad Khosrovi to vice president of development.

Millipore Corp. (Bedford, MA) named Barry D. Silver director of operations for its Waters Chromatography division.

Microgon (Laguna Hills, CA), a maker of microfiltration systems, appointed Gary M. Ernst vice president and chief operating officer.

Ecogen (Lawrenceville, NJ) promoted Mark J. DeNino to director of finance and administration, and named him treasurer. 